\title{
PENINGKATAN NILAI EKONOMIS LIMBAH PERTANIAN DI PEDESAAN MELALUI TEKHNOLOGI BOKASHI DIKELOMPOK TANI MARTAPURA, KABUPATEN BANJAR
}

\author{
Tintin Rostini ${ }^{1}$, Muhammad Irwan Zakir ${ }^{1}$, dan Danang Biyatmoko ${ }^{2}$ \\ 1). Fakultas Pertanian, Jurusan Peternakan, Universitas Islam Kalimantan \\ 2). Fakultas Pertanian, Jurusan Peternakan, Universitas Lambung Mangkurat \\ Email : tintin_rostini@yahoo.com
}

\begin{abstract}
ABSTRAK
Upaya pemanfaatan limbah tersebut menuntut pemanfaatan ilmu pengetahuan dan teknologi serta kemampuan manajerial yang semakin meningkat, untuk meningkatkan kualitas limbah pertanian. Tujuan kegiatan pengabdian ini adalah untuk meningkatkan nilai ekonomis limbah pertanian menjadi bokashi. Khalayak sasaran pada kelompok tani ternak Harapan Bersama di Kecamatan Martapura Kabupaten Banjar. Dengan cara Pelatihan teoritis (metode kelas) teknik pengolahan limbah pertanian menjadi bokashi. Parameter yang diukur tingkat pengetahuan peternak dan peningkatan niali ekonomis limbah pertanian. Hasil dari kegiatan terjadi peningkatan sebesar 70-90\% peningkatan ketrampilan dan pengetahuan peternak, adanya peningkatan nilai ekonomis limbah pertanian, dengan adanya kegiatan ini masyarakat berasa terbantu dengan paket teknologi yang diberikan sehingga dapat meningkatkan pendapatan masyarakat.
\end{abstract}

Kata Kunci: bokashi, pupuk, limbah, pertanian

\section{PENDAHULUAN}

Kabupaten Banjar merupakan salah satu kabupaten yang memiliki potensi untuk dijadikan sentra pengembangan sistem pertanian organik dengan memanfaatkan limbah-limbah pertanian dan peternakan yang cukup melimpah, mengikat Kabupaten banjar memiliki lahan pertanian yang cukup luas dan dan sentra peternakan sehingga banyak limbah ternak dan limbah pertanian yang belum termanfaatkan secara maksimal. Upaya pemanfaatan limbah tersebut menuntut pemanfaatan ilmu pengetahuan dan teknologi serta kemampuan manajerial yang semakin meningkat, untuk meningkatkan kualitas limbah pertanian (Rostini dan Biyatmoko 2019).

Untuk menjaga dan meningkatkan produktivitas pertanian khususnya tanaman perlu kiranya dimbangi dengan pemupukan yang baik. Akhir-akhir ini karena harga pupuk anorganik yang terus melambung tinggi peningkatan produktivitas lahan menjadi kurang optimal. Dengan demikian perlu dicarikan alternatif pengganti atau pensubstitusi pupuk anorganik dengan jenis pupuk organik yang ramah 
lingkungan, mudah dibuat, harganya murah serta dapat memanfaatkan limbah hasil pertanian yang ada di lingkungan petani - peternak. Cara ini juga diyakini akan mampu memperbaiki kondisi lahan dan tidak akan memutus rantai sistim ekologi pertanian yang ada.

Penerapan teknologi Effective Microorganisms $4 \quad\left(\mathrm{EM}_{4}\right)$ merupakan suatu teknologi alternatif yang memberikan peluang seluas-luasnya untuk meningkatkan dan menjaga kestabilan produksi tanaman pertanian (Wididana Dan Muntoyah. 1999). EM4 mengandung lactobacillus, ragi, bakteri fotosintetik, actinomycetes dan kapang pengurai serat selulose yang berfungsi memfermentasi bahan organic menjadi senyawa organic yang mudah diserap oleh akar tanaman. Cara kerja dari EM4 di dalam tanah yang secara sinergis dapat menekan populasi hama dan penyakit tanaman, meningkatkan kesuburan tanah secara fisik, kimia dan biologis sehingga dapat meningkatkan kesehatan pertumbuhan dan perkembangan tanaman.(Rostini, Ni'mah dan susilawati, 2016).

Salah satu hasil fermentasi bahan organic dengan inokulasi EM4 disebut dengan istilah BOKASHI, merupakan hasil fermentasi bahan organic (jerami, sampah organic, pupuk kandang, dll) yang dibuat hanya dalam beberapa hari dan bias langsung digunakan sebagai pupuk (syaifudin, 2000). Bokashi saat ini sudah mulai memasyarakat di wilayah kita karena bokashi mempunyai peranan besar dalam penyediaan pupuk organic secara cepat untuk memenuhi kebutuhan pupuk pada berbagai jenis tanaman pertanian.

Bokashi kini sangat berhasil digunakan pada tanaman padi, palawija, sayur, buah serta bunga yang memerlukan pupuk organik. Bokashi dapat merupakan kunci keberhasilan produksi pertanian dengan biaya yang murah dan teknologi yang mudah.

\section{Propil Khalayak/Kelompok Sasaran}

Kelompok tani ternak Harapan Bersama di Kecamatan Martapura Kabupaten Banjar ini merupakan Kelompok tani terbaik yang mudah menyerap teknologi baru dan unggul dalam kerjasama kelompok. Kerjasama dengan kelompok tani lain dan beberapa instansi sudah sering dilakukan dengan hasil yang baik. Kunci sukses kelompok ini adalah responsilititasnya tinggi untuk diajak maju. Manajemen kelompok sudah dikelola secara agribis dengan pembukuan yang mampu mereka terima bersama, termasuk 
program kerja, pelaksanaan kegiatan, bahkan keuangan dan modal untuk berinvestasi bersama-sama.

Khusus untuk mengelola kotoran sapi, dikelola secara tradisional yaitu dibiarkan begitu saja, dengan tujuan disimpan 4-6 bulan baru dimanfaatkan untuk pupuk pertanian/tanaman hijauan pakan ternak, pembelian pupuk anorgani dan pencampuran pupuk dilakukan pada saat penanaman bibit hijauan dilapangan, sedang pupuk anorganik biasanya mereka usahakan secara perorangan dan sebagaian kecil ada yang berkelompok dengan pergiliran disesuaikan dengan pertumbuhan tanaman hijauan yang ditanam dilahan kelompok. Kelompok tersebut menyisihkan dana untuk modal kerja dan ditangani manajer kelompok. Sehingga akan dapat meningkatkan pendapatan peternakan dengan memanfaatkan kotoran sapi/limbah ternak sebagai pupuk bokashi, yang memiliki nilai jual karena semuanya sudah berjalan teratur. Untuk meningkatan pendapatan kelompok .

\section{KONDISI PRODUKSI}

Selama ini kotoran ternak disimpan begitu saja tanpa tersentuh teknologi, sehingga tidak dapat dimanfaatkan secara maksimal, karena bila yang dapat dipakai adalah kotoran yang sudah tersimpan lama mengingat kotoran yang baru dikeluarkan dari tubuh hewan tidak dapat dipergunakan secara langsung menjadi pupuk kandang, tetapi harus difermentasikan terlebih dahulu untuk membentuk pupuk kandang yang matang melalui proses dekomposisi, dan biasanya baru dapat termanfaatkan dengan memerlukan waktu simpan selama kurang lebih 4-6 bulan baru dapat dipakai untuk pupuk.

Tujuan kegiatan ini adalah untuk Kegiatan Program Iptek ini bertujuan untuk :. Peningkatan keuntungan peternak dengan memanfaatkan kotoran ternak dan limbah pertanian dalam jangka waktu relatif singkat dengan cara . Melatih dan meningkatkan pengetahuan serta ketrampilan petani-peternak dalam pembuatan pupuk organik dengan teknologi Bokashi

\section{METODE PELAKSANAAN}

Secara keseluruhan kegiatan ini berlangsung selama 3 bulan, dengan rincian persiapan dan sosialisasi kegiatan (surat menyurat dan administrasi ) berlangsung 1 bulan, kegiatan utama yaitu pelatihan dan 
demonstrasi (demplot) berlangsung 1 bulan, monitoring dan evaluasi kegiatan (Monev) berlangsung 1 bulan, serta seminar dan laporan akhir hasil berlangsung 1 bulan.

Kegiatan pengabdian ini berlangsung dua tahap, yaitu :

Tahap Pertama : Pelatihan terstruktur (metode SWOT) bagi anggota kelompok sasaran untuk meningkatkan pemahaman dan skill beternak sapi utamanya.

Lama kegiatan berlangsung 4 minggu (1 bulan), dengan rincian 2 minggu adalah pendalaman materi kegiatan utama berupa kuliah tatap muka setiap minggu dengan mentor dengan metode partisipatif dan praktek lapangan selama 2 minggu dari setiap modul materi kuliah. Yaitu modul pelatihan yang disiapkan adalah Bokashi pupuk Kandang (1 kali tatap muka), Bokashi Jerami Padi (1 kali tatap muka), Bokashi Pupuk Kandang arang (1 kali tatap muka). lokasi kandang sapi potong dan kebun hijauan kelompok Tani Harapan Bersama, Desa Penggalaman Kecamatan Martapura Kabupaten Banjar.

1. Pelatihan dan Demontrasi pembuatan Bokashi jenis I : Bokashi Pupuk Kandang a. Praktek pembuatan, dengan tahapan :

- Pendalaman materi praktek bokashi pupuk kandang oleh mentor/pengajar

- Demonstrasi pembuatan, mengunakan bahan Pupuk kandang, Dedak padi, Sekam, Gula pasir, EM4 dan Air secukupnya. Waktu pembuatan hingga selesai : 4 hari

1. Cara pembuatan : Larutkan EM4 dan gula ke dalam air. Berlaku untuk berbagai bahan organic untuk setiap 1 ton bokashi diperlukan 1 liter EM4, Pupuk kandang, sekam dan dedak di campur secara merata. Siramkan larutan EM4 secara perlahan-lahan ke dalam adonan secara merata sampai kandungan air adonan mencapai $30 \%$. Bila adonan dikepal dengan tangan, air tidak keluar dari adonan dan bila kepalan dilepas maka adonan akan megar.

2. Adonan digundukkan di atas ubin yang kering 
dengan ketinggian $15-20$

$\mathrm{cm}$, kemudian ditutup

dengan karung goni,

selama 4 hari

3. Pertahankan suhu gundukan adonan $40-50^{\circ}$ C. Jika suhu lebih dari $50^{\circ}$ $\mathrm{C}$, bukalah karung penutup dan gundukan adonan dibalik balik, kemudian ditutup lagi dengan karung goni. Suhu yang tinggi dapat mengakibatkan bokashi menjadi rusak karena terjadi proses pembusukan. Pengecekan suhu dilakukan setiap 5 jam.

4. Setelah 4 hari, bokashi telah selesai terfermentasi dan siap digunakan sebagai pupuk organik

\section{Demontrasi Kedua.}

a. Pembuatan modul materi pelatihan pembuatan Bokashi jenis I : Bokashi Jerami Padi

b. Bahan yang digunakan : Jerami dipotong potong sepanjang 2-10 cm, Dedak padi, Sekam, Gula pasir, EM4, Air secukupnya
1. Cara pembuatannya : Larutkan EM4 dan gula ke dalam air. Berlaku untuk berbagai bahan organic untuk setiap 1 ton bokashi diperlukan 1 liter EM4.

2. Jerami, sekam dan dedak di campur secara merata. Siramkan larutan EM4 secara perlahan-lahan ke dalam adonan secara merata sampai kandungan air adonan mencapai $30 \%$. |Bila adonan dikepal dengan tangan, air tidak keluar dari adonan dan bila kepalan dilepas maka adonan akan megar.

3. Adonan digundukkan di atas ubin yang kering dengan ketinggian $15-20 \mathrm{~cm}$, kemudian ditutup dengan karung goni, selama 4 hari

4. Pertahankan suhu gundukan adonan $40-50^{\circ}$ C. Jika suhu lebih dari $50^{\circ} \mathrm{C}$, bukalah karung penutup dan gundukan adonan dibalik balik, kemudian ditutup lagi dengan karung goni. Suhu yang tinggi dapat mengakibatkan bokashi 
menjadi rusak karena terjadi

proses pembusukan.

Pengecekan suhu dilakukan setiap 5 jam.

5. Setelah 4 hari, bokashi telah selesai terfermentasi dan siap digunakan sebagai pupuk organik

\section{HASIL PEMBAHASAN}

\section{Evaluasi Terhadap Peserta}

Evaluasi kegiatan diukur berdasarkan partisipasi peserta kegiatan dalam setiap tahapan yang dilaksanakan dan terlaksananya semua rencana kegiatan yang telah disusun evaluasi pertama dilaksanakan pada saat penuyuluhan dan demntrasi kegiatan yang diberikan kepada peserta kegiatan indikator yang digunakan untuk mengukur keberhasilan kegiatan ini adalah :

Penyuluhan model PRA (partisipatif) dan curah pendapat / diskusi (braistorming) yang dilaksanakan menunjukkan secara umum bekal pengetahuan dan skill peternak di kelompok ternak berkisar 70-80 \% tergolong cukup baik untuk peternak.. Walaupun demikian pengetahuan dan skill yang mereka punya masih bersifat konvensional yang diperoleh dari pengetahuan turun temurun keluarganya sebagai peternak. Ide dan gagasan yang muncul dalam diskusi dan brainstorm yang dilaksanakan saat latihan belum banyak tersentuh dan teradopsi oleh tekhnologi baru peternakan, khususnya tekhnologi pakan ternak. Oleh karena itu masih sangat perlu untuk ditingkatkan lagi pengetahuan dan skill mereka dengan pengolahan limbah pertanian dengan teknolohi bokhasi yang mereka perlukan adalah yang mudah dilakukan, biaya murah dan mampu memberi manfaat yang menguntungkan.

Teknologi pembuatan bokashi berbahan limbah pertanian/peternakanl yang diberikan dalam pengabdian ini adalah tekhnologi yang tepat bagi mereka, dimana limbah pertanian/peternakan belum dimanfaatakan secara maksimal dengan memiiki nilai dekonomis yang tinggi.. Dengan demikian kegiatan yang diberikan dalam program pengabdian ini sangat baik direspons mereka untuk meningkatkan pendapatan masyarakat setempat. Kecenderungan antusisme peternak menerima secara baik penyuluhan yang dilaksanakan dicerminkan oleh respons yang tinggi dalam ketepatan waktu kehadiran, 
kehadiran peserta dalam kegaiatn penyuluhan dan curah pendapat (brainstorming) dengan prosentase antara $90-100 \%$. Selain itu disisi lain terlihat dari keaktifan dalam mengemukakan ide dan gagasan, serta keberanian dalam bertanya cukup baik masing-masing. Hasil akhir yang baik dari tahap ini adalah adanya peningkatan pemahaman dari pengetahuan dan skill mereka setelah pelatihan, ditunjukkan dengan meningkatnya nilai post test yang diberikan di akhir kegiatan pelatihan yang dilaksanakan dari 50-60 \% meningkat menjadi $60-80 \%$.

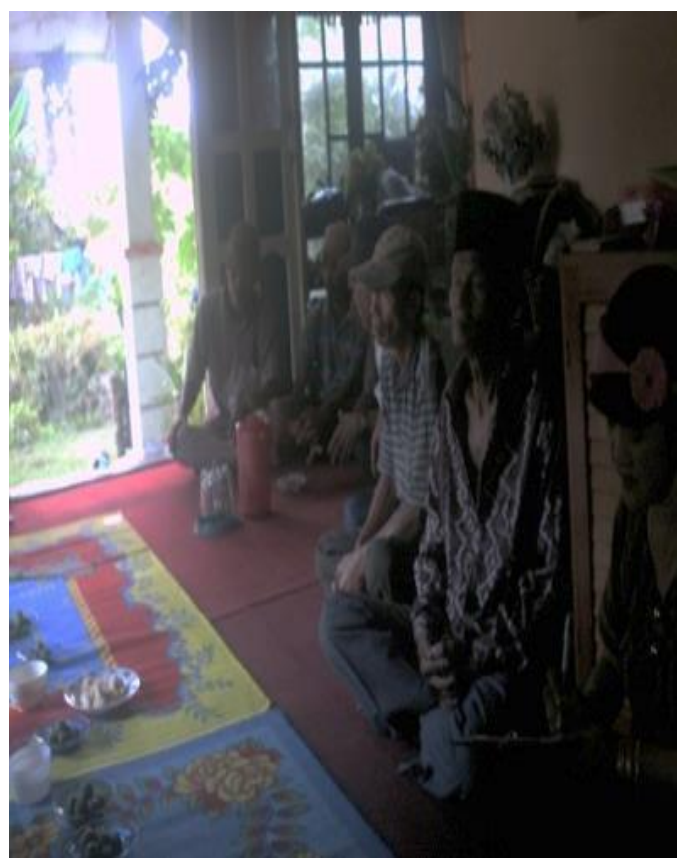

Gambar A. Penyuluhan

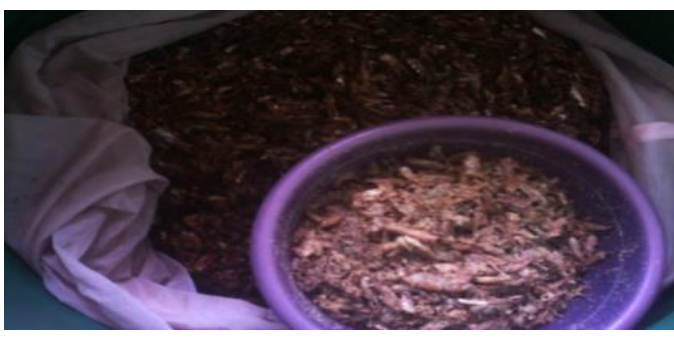

Gambar B. Bahan yang digunakan

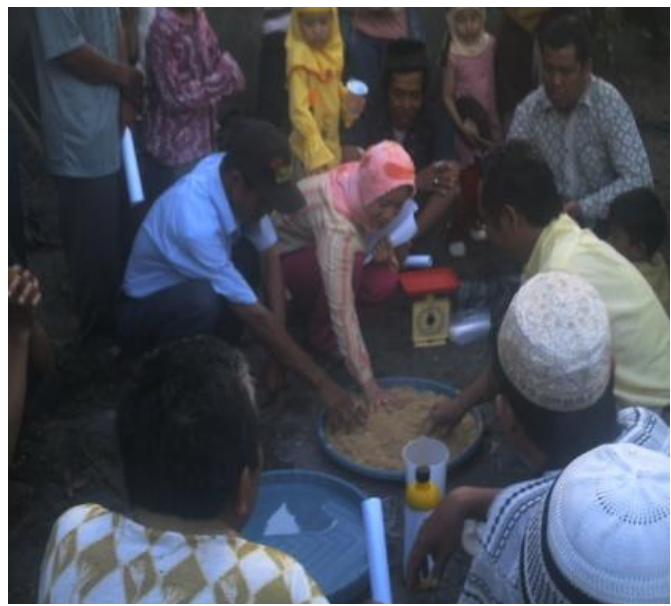

Gambar C. Demonstrasi pembuatan bokhasi

Monitoring dan evaluasi dilakukan pada kegiatan ini untuk mengukur tingkat keberhasilan kegiatan berdasarkan tolok ukur yang dibuat. Dimana para peserta sangat antuis sekali dalam mempelajari teknologi bokashi., dan diharapkan setelah mengikuti pelatihan ini peserta memahami dan dapat menerapkan pembuatan boshi sehingga secara nilai ekonomis dapat meningkatkan pendapatan petani.. Hasil evaluasi kegiatan tersaji pada Tabel 1. 
Tabel 1. Penilai pada kegiatan pengabdian ini

\begin{tabular}{|c|c|c|c|c|}
\hline \multirow[b]{2}{*}{ No } & \multirow[b]{2}{*}{ Kegiatan } & \multicolumn{3}{|c|}{ Kualifikasi Hasil Kegiatan } \\
\hline & & $\begin{array}{l}\text { Baik } \\
\text { (nilai : } \\
>80 \text { ) }\end{array}$ & $\begin{array}{c}\text { Sedang } \\
\text { (nilai : } 65- \\
80)\end{array}$ & $\begin{array}{l}\text { Kurang } \\
\text { (nilai : } \\
<65 \text { ) }\end{array}$ \\
\hline 1 & $\begin{array}{l}\text { Kemampuan teknis peserta dalam : } \\
\text { - Bokashi Pupuk Kandang } \\
\text { - Bokashi Jerami Padi } \\
\text { - Bokashi Pupuk Kandang Arang }\end{array}$ & $\mathrm{X}$ & & \\
\hline 2 & $\begin{array}{l}\text { Keaktifan dalam setiap kegiatan } \\
\text { Pembuatan Bokashi }\end{array}$ & & $\mathrm{X}$ & \\
\hline 3 & $\begin{array}{l}\text { Kemampuan mengemukakan } \\
\text { ide/gagasan }\end{array}$ & $\mathrm{X}$ & & \\
\hline 4 & Keaktifan dalam diskusi kelompok & $X$ & & \\
\hline 5 & Pemahaman materi yang disampaikan & & $\mathrm{X}$ & \\
\hline 6 & Andil dalam kegiatan kelompok & $X$ & & \\
\hline 7 & Keahlian pembuatan Bokashi & $\mathrm{X}$ & & \\
\hline 8 & Kreatifitas & & $\mathrm{X}$ & \\
\hline 9 & $\begin{array}{l}\text { Kemampuan mempengaruhi dalam } \\
\text { kelompok }\end{array}$ & & $\mathrm{X}$ & \\
\hline 10 & Kepribadian & $X$ & & \\
\hline
\end{tabular}

Berdasarkan Tabel 1. Terlihat bahwa peserta pelatihan sangat antusias dalam kegiatan ini pengabdian dilihat bersarkan keaktifan dan diskusi kelompok yang dilakukan. Hasil yang diperoleh menunjukkan peningkatan nilai ekonomis limbah pertanian, dimana yang awalnya limbah pertanian tidak ada $n$ ilainya menjadi memiliki nilai ekonomis yaitu menjadi pupuk bokashi dengan nilai harga jual pupuk sebesar Rp 5000,- untuk 5 Kg bokashi.

\section{KESIMPULAN}

Simpulan dari kegiatan pengabdian ini dapat membantu meningkatkan ketrampilan petani/ peternak dalam inovasi baru teknologi pemanfaatan limbah ternak dan limbah pertanian yaitu pemanfaatan kotoran ternak dan sisa pertanian sebagai pupuk yang bernilai ekonomi dengan kualitas hara yang baik untuk tanaman hijauan pakan ternak

\section{DAFTAR PUSTAKA}

Rostini T, Biyatmoko D. 2019. Performance of kacang goats fed with complete wafered forage based on Palm plantation waste. Pakistan Journal Of Nutrition. Vol 18 N $6: 514-5180$

Rostini T, Ni'Mah GK., Sosilawati S. 2016. Pengaruh Pemberian Pupuk Bokashi yang berbeda terhadap Kandungan Protein dan Serat Kasar . Rumput gajah (Pennisetum Purpureum). Jurnal Ziraah majalah Ilmiah Pertanian Vol 41N0 1: 118-126 
Syaifudin, 2000. Pengaruh Pemberian Dosis Pupuk N,P,K, dan pupuk bokashi terhadap pertumbuhan tanaman lkacang-kacangan. Skripsi Fakultas Pertanian UNLAm, Banjarbaru.

Soesono, S. 1988. Untuk Apa Mereka Memakai Bokashi, Trubus XXIX (346):58-59

Wididana, G.N. dan Higa, 1994. Peranan Efective Mikroorganism-
4 Dalam Meningkatkan kesuburan dan Produktivitas Tanah. Indonesia Kyusei Nature Farming Societies. Jakarta

Wididana C. N. Dan Muntoyah. 1999. Teknologi EM-4 Dimensi Baru dalam Bidang Pertanian Modern. Istitut Pengembangan Sumber Daya Alam (IPSDA).Jakarta 